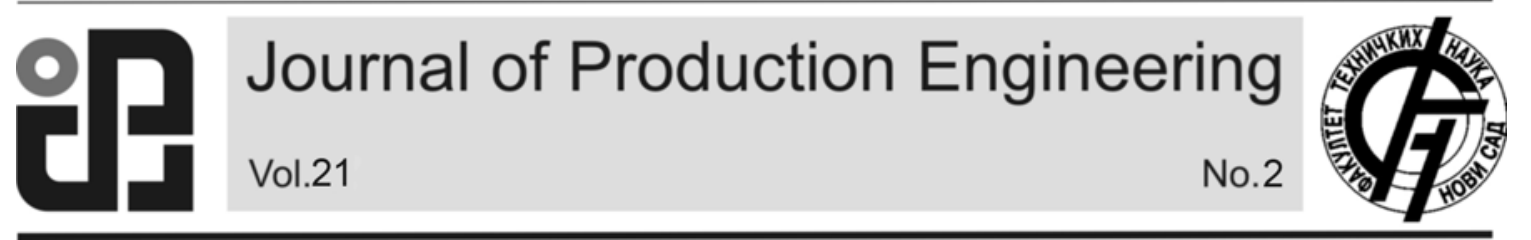

JPE (2018) Vol.21 (2)

Choudhary, M., Narang, R., Khanna, P.

Original Scientific Paper

\title{
MATHEMATICAL ANALYSIS OF PERFORMANCE OF A VIBRATORY BOWL FEEDER FOR FEEDING BOTTLE CAPS
}

Received: 17 September 2018 / Accepted: 29 November 2018

\begin{abstract}
Modern manufacturing processes demand high degree of automation in mass production units. In order to achieve the predetermined cycle times, synchronization of different processes in the automated production lines, is of utmost importance. Automating the feeding process also leads to reduction of waste and labour costs and increase in efficiency. Often, discrete part feeding, along with other variable parameters can give optimum Feed rates as results. A suitable feeding mechanism needs to be chosen for this purpose, we use a vibratory bowl feeder for its ease of use and its versatile nature. The present study is aimed at mathematically analysing the behaviour of a vibratory bowl feeder with different sizes of tube caps used in the pharmaceutical industry and other consumer goods industries. The response parameter chosen for this investigation was the feed rate and the various input parameters for the study were - part population, part size and frequency of bowl. Once the experimental readings were obtained, a mathematical model was developed using Design of experiments statistical package, expressing the relationship between input and response parameters in the equational form. Significance testing of the developed model was performed using Analysis of Variance (ANOVA). Response surface methodology was then used to optimise the obtained model which can be used to predict the behaviour of the feeder.
\end{abstract}

Key words: automation, feed rate, mathematical analysis, response surface methodology, ANOVA.

Matematička analiza performansi vibrirajućeg dozatora pri doziranju čepova za flaše. Savremeni proizvodni procesi u masovnoj proizvodnji zahtevaju visok stepen automatizacije. Da bi se postiglo unapred određeno vreme ciklusa, sinhronizacija različitih procesa u automatizovanim proizvodnim linijama je od najveće važnosti. Automatizacija procesa doziranja dovodi do smanjenja troškova otpada, rada i povećanja efikasnosti. Često, doziranje diskretnih delova, zajedno sa drugim promenljivim parametrima, može dati optimalne vrednosti dozatora. U tu svrhu je potrebno odabrati odgovarajući mehanizam za doziranje, mi smo koristili vibracioni dozator zbog jednostavne upotrebe i svestrane primene. Ova studija ima za cilj da matematički analizira ponašanje vibracione posude za doziranje sa različitim veličinama čepova za flaše koje se koriste u farmaceutskoj industriji, kao i drugim proizvodima široke potrošnje. Izlazni parametar, izabran za ovo ispitivanje, bio je brzina doziranja, a razni ulazni parametri za ispitivanje bili su - deo stanovništva, veličina i frekvencija posude. Nakon dobijanja eksperimentalnih očitavanja, razvijen je matematički model korišćenjem statističkog paketa "Izrada plana eksperimenta", izražavajući odnos između ulaznih i izlaznih parametara u obliku jednačine. Testiranje značajnosti razvijenog modela izvršeno je korišćenjem Analize varijanse (ANOVA). Metodologija odzivne površine je zatim korišćena za optimizaciju dobijenog modela koji se može koristiti za predviđanje ponašanja dozatora.

Ključne reči: automatizacija, brzina punjenja, matematička analiza, metodologija odzivne površine, ANOVA.

\section{INTRODUCTION}

A feeder is a machine or device that is used to feed any kind of material, chemical or product to the assembly line, manufacturing stations or wherever necessary. The feeder serves the very important purpose of automating the assembly process which was previously largely dominated by manual labour, hence reducing costs, improving efficiency and better results.

The feeder used during this experiment is Vibratory Bowl Feeder. It is an instrument that uses vibration to feed material. Both vibration and gravity are used to move materials in this feeder. Direction is determined by gravity, either down, or down and to a side, and then material is moved by vibration. They are mainly used to transport smaller objects in large quantity.

A number of research papers have been surveyed to understand the importance of mechanized feeding and to study the various techniques used by the experimenters to analyse the behaviour of these feeders.

Taguchi approach was applied by Jain et. al. [1,2] in order to optimise the performance of vibratory bowl feeder and it was found that part population had a negative effect on feed rate whereas, frequency had a positive effect on feed rate. Initially, the part size had a negative effect but owing to its interaction with frequency and part population, it became positive after a while.

In the investigation carried out by Jindal et. al. [3] graphical and mathematical analysis of vibratory bowl feeder using clip shaped components revealed that the highest frequency with the highest part population was exhibiting the maximum feed rate for the smallest part size in the graphical analysis.

According to Chauhan et. al. [4], the factorial approach to study the effects that various parameters had on the feeder gave satisfactory results.

Bhagat et. al. [5, 6], analysed graphically and 
mathematically, the behaviour of the vibratory bowl feeder for feeding headed components and it was concluded that the mathematically developed model could estimate the magnitude and direction of the effects of variation in factors as well as predicts the effects of their mutual interactions.

\section{PLAN OF INVESTIGATION}

The Investigations were carried out in the following steps:

1. Identifying process parameters and their working ranges

2. Developing of the design matrix

3. Conducting the experiments as per the design matrix

4. Recording the observations

5. Formulation of mathematical model

6. Testing the significance of the model

7. Results and their analysis

8. Conclusions

\subsection{Identification of process parameters and their working ranges}

There are many part parameters, process parameters which were observed to affect the behaviour of the feeder. These parameters are part population, part size, frequency, part weight, part material, part height and shape. A number of trial experiments however showed that frequency, part size and part population were the most significant process parameters from the lot and were therefore, chosen as input parameters for the investigation. A series of trial experiments were conducted to figure out the working ranges of these input parameters. These ranges are shown in table 1 . The upper limit is represented by $+1 \&$ the lower limit by -1 .

\begin{tabular}{|l|c|c|c|}
\hline Process Parameters & $(-1)$ & $(0)$ & $(+1)$ \\
\hline Frequency & 45 & 47.5 & 50 \\
\hline Part Size & 16 & 19 & 22 \\
\hline Part Population & 45 & 90 & 135 \\
\hline
\end{tabular}

Table 1. Process parameters and their working ranges

\subsection{Development of Design Matrix}

To analyse the individual and interaction effects of process parameters, design of experiment's statistical approach was chosen. Central composite face centred technique was applied to decide the number of experiments to be conducted as per the design matrix given in table 2. A total of $20 \quad\left(2^{3}+2 * 3+6=20\right)$ experiments were conducted with single replication and the corresponding readings for feed rate were recorded in Table 2 .

\subsection{Conducting the experiments as per the design matrix}

The experiments were conducted on a frequency bowl feeder with the bowl having a diameter of $300 \mathrm{~mm}$ whose vibrating frequency has been controlled using a frequency control unit, which allows stepless control of vibrational frequency that acts as an important factor affecting the feed rate of this feeder.

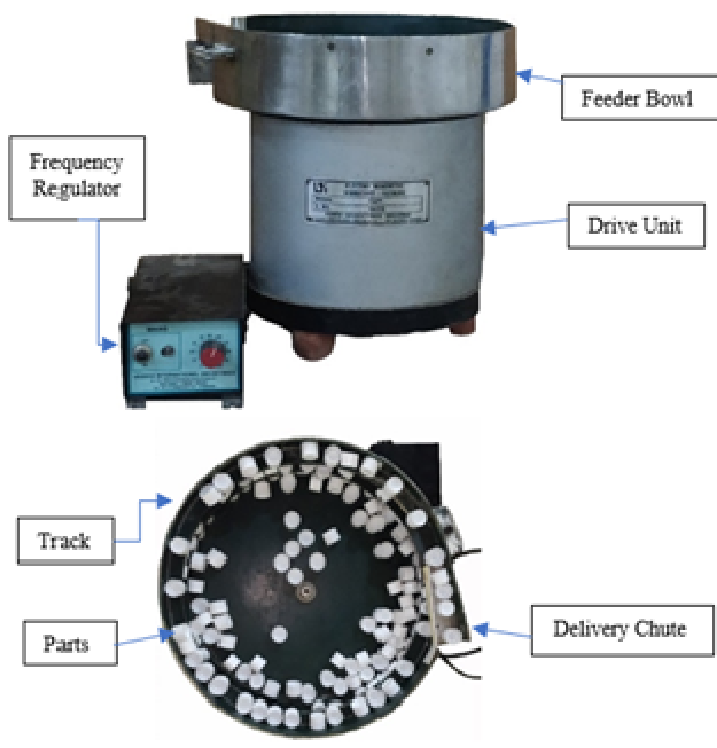

Fig. 1. The experimental set up

\subsection{Recording the observations}

Design of matrix's statistical approach was opted and 20 experiments were conducted as per the design matrix. The observations have been shown in table 2 .

\begin{tabular}{|c|c|c|c|c|}
\hline Run & $\begin{array}{c}\text { Factor } 1 \\
\text { A:Frequency } \\
\mathrm{Hz}\end{array}$ & $\begin{array}{c}\text { Factor } \overline{2} \\
\text { B:Part Population }\end{array}$ & $\begin{array}{c}\text { Factor } 3 \\
\text { C:Size } \\
\text { mm }\end{array}$ & $\begin{array}{l}\text { Response } 1 \\
\text { Feed Rate } \\
\text { parts/min }\end{array}$ \\
\hline 1 & 0 & -1 & 0 & 80 \\
\hline 2 & 0 & 0 & 0 & 110 \\
\hline 3 & -1 & 0 & 0 & 108 \\
\hline 4 & 0 & 0 & 0 & 111 \\
\hline 5 & 1 & 1 & -1 & 182 \\
\hline 6 & 0 & 0 & 0 & 109 \\
\hline 7 & -1 & -1 & 1 & 75 \\
\hline 8 & 0 & 0 & -1 & 141 \\
\hline 9 & 1 & 0 & 0 & 113 \\
\hline 10 & 0 & 0 & 0 & 115 \\
\hline 11 & 0 & 0 & 0 & 114 \\
\hline 12 & -1 & 1 & -1 & 171 \\
\hline 13 & -1 & -1 & -1 & 83 \\
\hline 14 & 0 & 1 & 0 & 145 \\
\hline 15 & 0 & 0 & 0 & 115 \\
\hline 16 & 1 & -1 & -1 & 93 \\
\hline 17 & 0 & 0 & 1 & 87 \\
\hline 18 & 1 & 1 & 1 & 93 \\
\hline 19 & -1 & 1 & 1 & 104 \\
\hline 20 & 1 & -1 & 1 & 43 \\
\hline
\end{tabular}

Table 2. Recording of observations

\subsection{Development of mathematical model}

"Feed rate $=\mathrm{f}(\mathrm{A}, \mathrm{B}, \mathrm{C})$ " represents response parameters i.e. feed rate as a function of input parameters (part size, part population and frequency)

The general regression equation is

feed rate $=\beta_{0}+\beta_{1} \mathrm{~A}+\beta_{2} \mathrm{~B}+\beta_{3} \mathrm{C}+\beta_{12} \mathrm{AB}+\beta_{13} \mathrm{AC}+$ $\beta_{23} \mathrm{BC}+\beta_{11} \mathrm{~A}^{2}+\beta_{22} \mathrm{~B}^{2}+\beta_{33} \mathrm{C}^{2}$

where $\beta_{1}, \beta_{2}, \beta_{3}$ are regression coefficients for linear terms

$\beta_{12}, \beta_{13}, \beta_{23}$ are regression coefficients for interaction

$\beta_{11}, \beta_{22}, \beta_{33}$ are regression coefficients for square terms.

The actual regression equation for the developed model is given below

Feed rate $=82+66.5 \mathrm{~A}+15 \mathrm{~B}+18.5 \mathrm{C}+5.87 \mathrm{AB}+33.12 \mathrm{AC}$ $18.88 \mathrm{BC}+3 \mathrm{~A}^{2}-4.5 \mathrm{~B}^{2}+\mathrm{C}^{2}$ 


\subsection{Testing the significance of the model}

The significance of the developed model and lack of Fit was tested using ANOVA technique with the help of Design Expert software whose results are given in Table 3. It is evident that the developed model is significant and the lack of fit is insignificant. Further, the Fit
Statistics table given in Table 4 also verifies the claim by a significantly high value of $\mathrm{R}^{2}$. The scatter diagram between predicted and actual value shown in Fig. 2, also corroborates the fact that model is significant because of the close proximity of predicted and actual values on the scatter diagram.

\begin{tabular}{|c|c|c|c|c|c|c|}
\hline Source & Sum of squares & df & Mean Value & f-value & p-value & \\
\hline Model & 19504.49 & 9 & 2167.17 & 144.18 & $<0.0001$ & significant \\
\hline A-Frequency & 28.90 & 1 & 28.90 & 1.92 & 0.1957 & \\
\hline B-Part Size & 10304.10 & 1 & 10304.10 & 685.53 & $<0.0001$ & \\
\hline C-Part Population & 7182.40 & 1 & 7182.40 & 477.84 & $<0.0001$ & \\
\hline $\mathrm{AB}$ & 60.50 & 1 & 60.50 & 4.03 & 0.0726 & \\
\hline $\mathrm{AC}$ & 512.00 & 1 & 512.00 & 34.06 & 0.0002 & \\
\hline $\mathrm{BC}$ & 1200.50 & 1 & 1200.50 & 79.87 & $<0.0001$ & \\
\hline $\mathrm{A}^{2}$ & 51.28 & 1 & 51.28 & 3.41 & 0.0945 & \\
\hline $\mathrm{B}^{2}$ & 14.78 & 1 & 14.78 & 0.9832 & 0.3448 & \\
\hline $\mathrm{C}^{2}$ & 1.84 & 1 & 1.84 & 0.1225 & 0.7336 & \\
\hline Residual & 150.31 & 10 & 15.03 & & & \\
\hline Lack of Fit & 114.98 & 5 & 23.0 & 3.25 & 0.1106 & not significant \\
\hline Pure Error & 35.33 & 5 & 7.07 & & & \\
\hline Cor Total & 19654.80 & 19 & & & & \\
\hline
\end{tabular}

Table 3. ANOVA Analysis

\begin{tabular}{|c|c|c|c|}
\hline Std. Dev. & 3.88 & $\mathbf{R}^{\mathbf{2}}$ & 0.9924 \\
\hline Mean & 109.60 & Adjusted R $^{\mathbf{2}}$ & 0.9855 \\
\hline C.V. \% & 3.54 & Predicted R & 0.9163 \\
\hline & - & Adeq Precision & 50.8128 \\
\hline & & & \\
\hline
\end{tabular}

Table 4. Fit Statistics

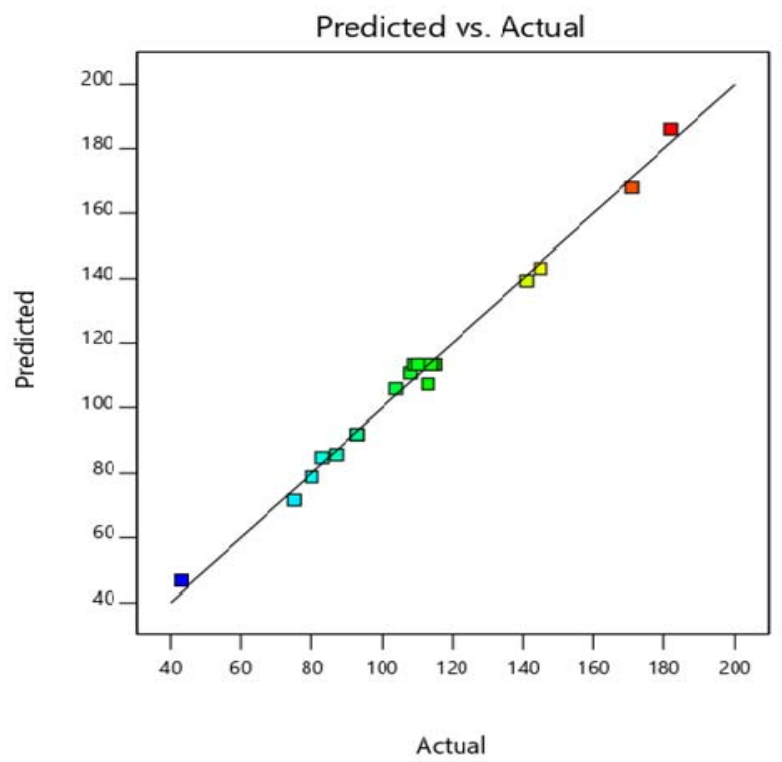

Fig. 2. Predicted v Actual scatter diagram

\subsection{Results and their analysis}

The results of the investigative work performed so far has been depicted in the form of pictorial graphs in figures. 3-6.

The analysis of these results is explained as below

\subsubsection{Direct effect of Frequency on feed rate}

Feed Rate has been found to increase with increase in Frequency. This could be explained by the fact that increased frequency resulted in more agitation of the components which lead to an increased pushing tendency among components, driving them towards the delivery chute, hence positively affecting the feed rate.

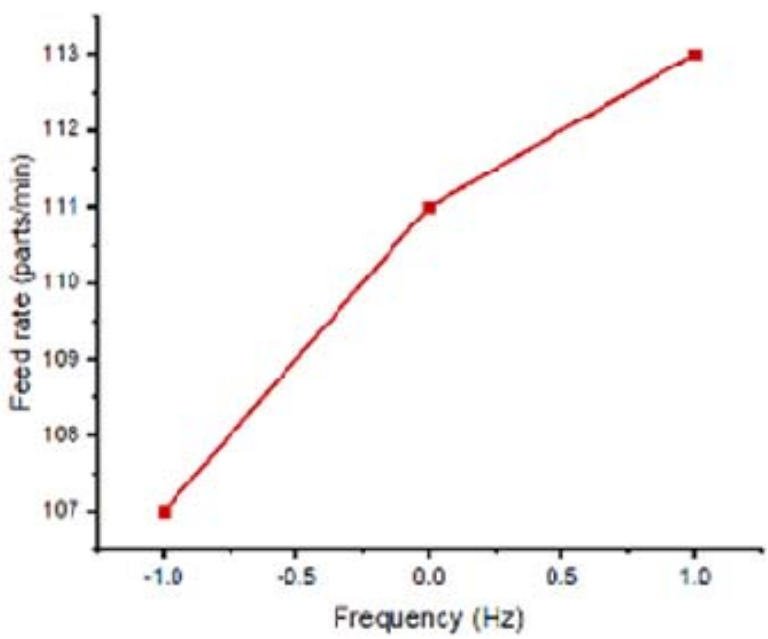

Fig. 3. Effect of frequency on feed rate

\subsubsection{Direct effect of Part size on feed rate}

It was found that increase in part size led to decrease in feed rate. A possible explanation for this trend could be that with increased part size, component mass also increased thus granting it more stability towards the same amount of agitation. Increase in diameter must have contributed to the increase in fall-back factor due 
to which larger sizes exhibited the tendency to fall back from the tracks into the bowl before reaching the delivery chute.

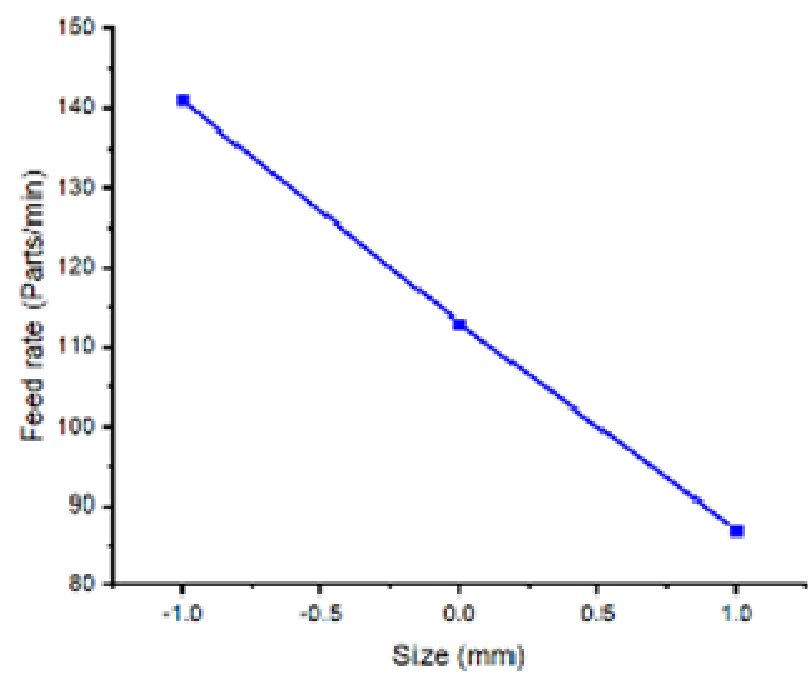

Fig. 4. Effect of part size on feed rate

\subsubsection{Direct effect of Part population on feed rate}

Figure 5 shows an increasing trend in feed rate on being subjected to increase in the part population inside the bowl. This could be due to the reason that with increase in part population the number of effective interactions between components within the bowl increase, resulting in components being pushed up the tracks at a faster rate, which as a result shows an increase in the feed rate.

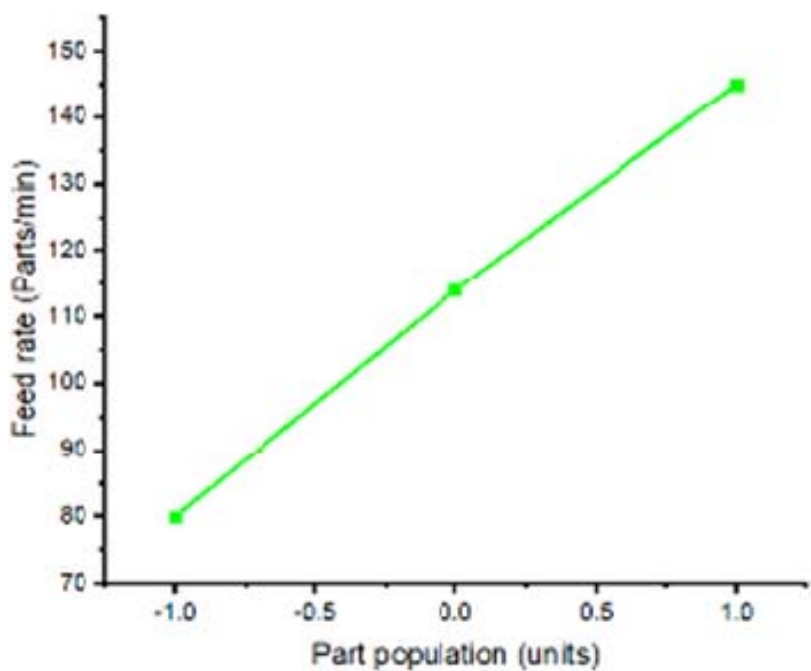

Fig. 5. Effect of part population on feed rate

\subsubsection{Interaction effects of Part size and Part population on feed rate}

The interaction curve in Figure 6 shows that both part size and part population have positive effect on the feed rate, with part population having more dominating one and has outweighed the negative effect of part size when taken as a single factor. This also, explains that the behaviour of a factor may change drastically when taken in interaction with other factors.

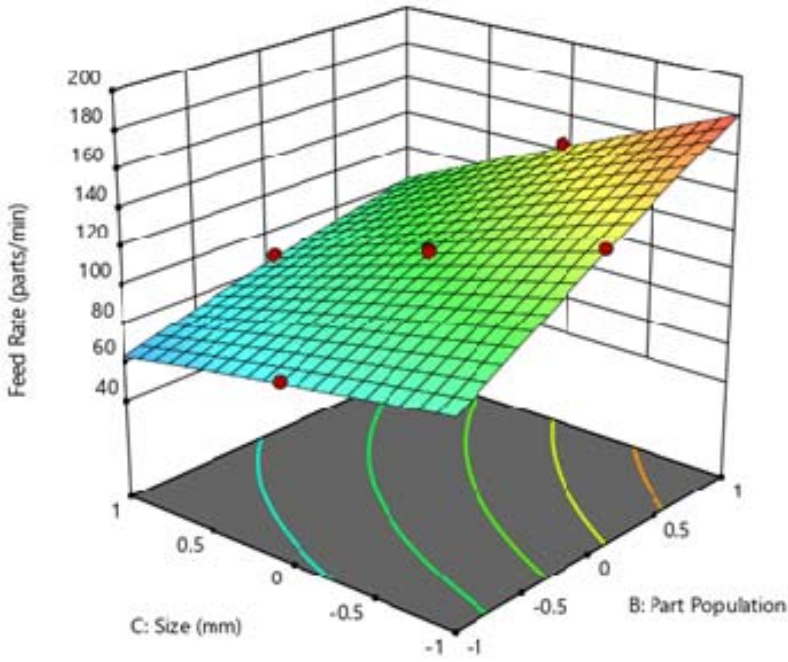

Fig. 6. Effects of part size and part population on feed rate

\subsubsection{Interaction effects of Frequency and Part population on feed rate}

The interaction effects exhibited in Figure 7 show that while Part Population has a positive effect on feed rate whereas the effect of frequency remains negligible. This could be explained as, though these parameters have a positive effect when taken independently, but when taken together, the effect of frequency seems subsided this could be to keep the feed rate within practical deliverable rates.

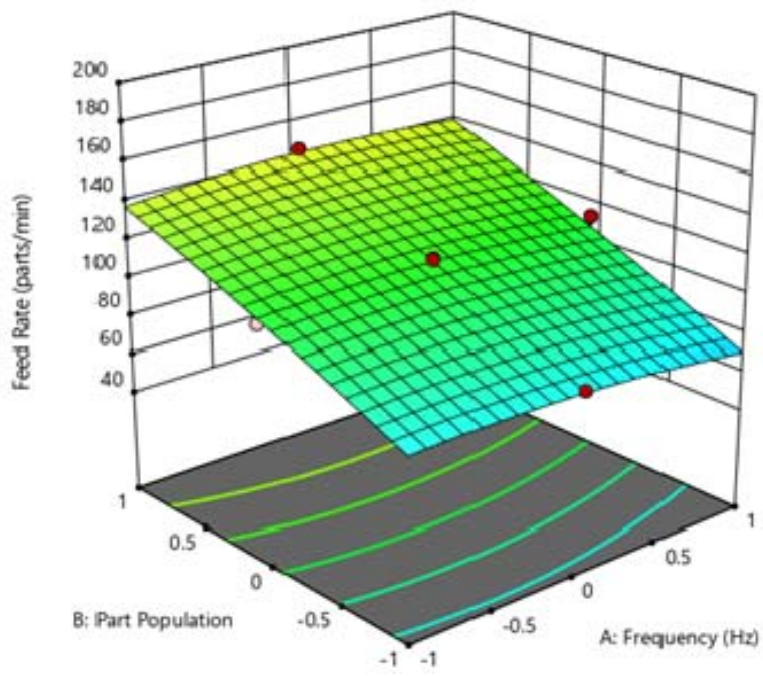

Fig. 7. Effects of frequency and part population on feed rate

\subsubsection{Interaction effects of Frequency and Part size on feed rate}

The graph in Figure 8 shows the effect of part size and frequency on feed rate. It is very evident from the graph that with increase in frequency, the feed rate increases and with increase in part size there is an increase in feed rate Moreover, for lower frequency but for higher frequency, the slope of the part size $\mathrm{v}$ feed rate curve increases. 


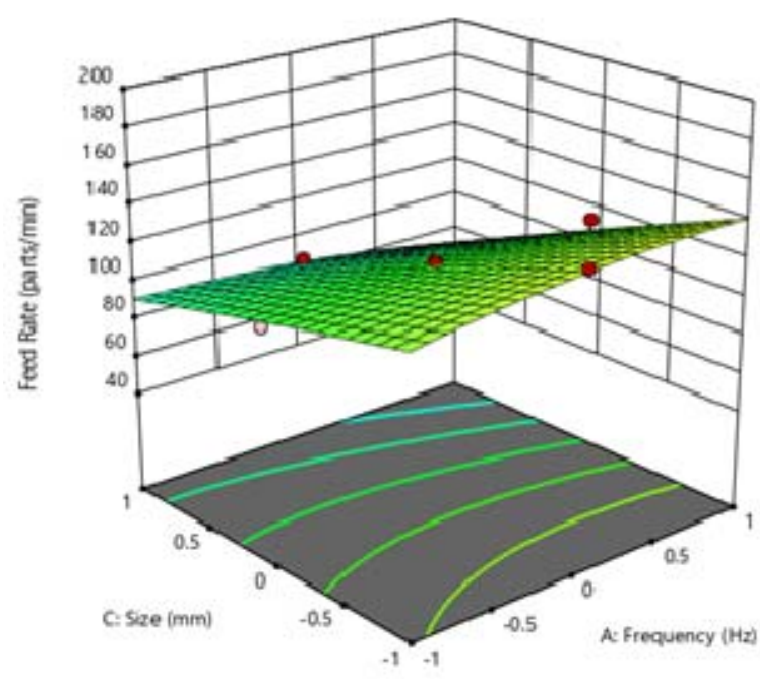

Fig. 8. Effects of part size and frequency on feed rate

\section{CONCLUSIONS}

1. Central composite face centred has been found to be satisfactory and useful in predicting the behaviour of a vibratory bowl feeder.

2. Part population and frequency were found to have positive effect on feed rate, whereas part size was found to have a negative effect on the feed rate, when factors are taken individually.

3. Increase in part population shows an increase in feed rate. When interaction effects of part population and part size are considered, feed rate exhibits an increasing trend with increase in part population but a decreasing trend fir increase in part size.

4. Part population was found to have positive effect on feed rate, whereas Frequency seemed to have no effect on the feed rate when interaction effects were considered.

5. Part size was found to have a positive effect on feed rate. However, it was observed that, for larger part sizes, frequency had a negative effect on the feed rate whereas for smaller sizes, frequency had a positive effect.

\section{REFERENCES}

[1] Jain, A., Bansal, P., Khanna, P., "Application of Taguchi Technique to Optimize the Performance of a Vibratory Bowl Feeder". Global Journal on Innovation, Opportunities and Challenges in AAI and Machine Learning, Vol. 1, pp. 13-18, Issue 1,2017 .

[2] Jain, S., Jindal, U., Piyush, Khanna, P., "Mathematical Analysis of Vibratory Bowl Feeder for Clip Shaped Components". Journal of Production Engineering, Vol.20, pp. 122-126, 2017.

[3] Jindal, U., Jain, S., Piyush, Khanna, P., "Graphical Analysis of a Vibratory Bowl Feeder for Clip shaped Components". IJISET - International Journal of Innovative Science, Engineering \& Technology, Vol. 4 Issue 2, pp. 279-283, February 2017.

[4] Chauhan, A., Nirman, G., "Mathematical Analysis of U-shaped Components in a Vibratory Bowl Feeder". International Journal of Electronics, Electrical and Computational Systems, Vol. 5, Issue 4, pp. 91-99, April, 2016.

[5] Bhagat, S., Pandey, T., Garg, V., Khanna, P., "Design, Fabrication and Analysis of Vibratory Feeder". IJRMET, Vol. 4, Issue 1, pp. 73-75, November 2013 - April 2014.

[6] Bhagat, S., Pandey, T., Garg, V., Khanna, P., "Mathematical Analysis of Vibratory Bowl Feeder". International Journal of Latest Trends in Engineering and Technology, Vol 4, Issue 1, pp. 315-324, 2014.

Authors: Manas Choudhary, student, Department of Mechanical Engineering, Delhi Technological University, Delhi-11042, Rishabh Narang, student, Pradeep Khanna, Associate Prof., Division of MPAE, Netaji Subhash Institute of Technology, New Delhi, India -110078 .

E-mail: manaschoudharywork@gmail.com rishabh.narang102@gmail.com 4.khanna@gmail.com 